\title{
„Od lokální k cikánské škole“: homogenizace školní třídy a měnící se role učitele 1
}

\author{
Irena Kašparová, Adéla Souralová \\ Masarykova univerzita, Fakulta sociálních studií
}

\begin{abstract}
Abstrakt: Tento článek je př́padovou studií dvou základních škol, navštěvovaných především romskými dětmi, na kterých došlo k etnické homogenizaci. V textu popisujeme proces segregace, tedy změny od lokální k „cikánské” škole, a dopady, které tato změna měla na tamější žáky a vyučující. Interpretujeme tento proces jako výsledek individuálních rozhodnutí zainteresovaných aktérů - konkrétně rodičů (romských a neromských), vyučujících a vedení školy - které zasazujeme do strukturního kontextu etnických a socioekonomických nerovností. Zároveň věnujeme pozornost dopadům takovéto nové konstelace ve složení žákovské populace na měnící se status škol a její percepci vyučujícími na námi zkoumaných školách - sledujeme tedy reprodukci strukturálního statu quo. Tento text vznáší zásadní otázky týkající se fungování určitého typu škol - od každodenního učení se (žáci), vyučování (učitelé) až po strukturální pohled na ekonomické fungování těchto škol, jejich symbolickou pozici na mapě základních škol, jakož i otázky přesahující budovy těchto škol směřující k připravenosti vyučujících vyučovat na „cikánských školách“.
\end{abstract}

Kličová slova: segregace, Romové, sociální vyloučení

\section{„From Local to Gypsy School“: Homogenization of School Class and Changing Role of Teachers}

Abstract: The article is a case study of two primary schools (which educate children ages 6-16), where almost all the pupils are Roma. We describe the genesis of the process through which segregation (i.e. changing from a "local" to a "gypsy" school) was established, as well as the outcomes of it, which included a massive outflow of both teachers and non-Roma pupils from the schools. We pay close attention to the changing status of the schools, as well as the impact of the transformation upon the remaining teachers. Voice is also given to the Roma parents whose children go to these schools, as well as the school's representatives (directors, deputies and local politicians) responsible for the financial running of the schools. Overall, the presented data shows a colourful mosaic of segregation, one which officially does not exist, and for which there is no solution easily acceptable to all those affected.

Keywords: segregation, Roma pupils, social exclusion

Vlivem demografických změn v populaci dochází v těchto letech k úbytku žáků na mnoha školách napříč republikou. Jedním z řešení, jak se k tomuto faktu postavit, je slučování škol, které jsou si prostorově blízké. Naše studie popisuje jeden takový

1 Ranější verze tohoto textu byla prezentována na 2nd Belgrade International Conference on Education, konferenci konané v Bělehradě ve dnech 14. až 16. listopadu 2013. Děkujeme všem informátorkám a informátorům, kteří se s námi podělili o jejich každodenní zkušenosti. Velký dík patři anonymním recenzentům a redakci časopisu Orbis Scholae za jejich inspirativní připomínky, které pomohly tento text vylepšit. 
80 případ, s tou zvláštností, že se jedná o školy, které v minulém desetiletí navštěvovaly převážně dvě různé skupiny - konkrétně Romové a ne-Romové. Přestože jsou takové školy $v$ České republice $v$ menšině, během posledních deseti let jich napřič naší zemí výrazně přibylo a jejich zkušenosti jsou velmi podobné. Rádi bychom tímto textem vypověděly nejen o specifických problémech takových škol, ale chceme rovněž přispět do debaty o vzdělávání dětí z minorit, která se na stránkách časopisu Orbis Scholae nárazově objevuje (viz např. Němec, 2009).

Cílem tohoto textu je na príkladu dvou konkrétních událostí interpretovat změny ve složení školní třídy, popsat mechanismy vedoucí k homogenizaci (romizaci) dvou základních škol nacházejících se v sociálně vyloučené lokalitě ve městě, které budeme nazývat Barviřov², a diskutovat role a postavení učitele ve vzdělávání dětí z vyloučených lokalit. Na následujících řádcích popisujeme proces, jehož prostřednictvím došlo $\mathrm{k}$ homogenizaci (segregaci) dvou škol, tedy ke změně z lokální v „cikánskou“. Interpretujeme tento proces jako výsledek individuálních rozhodnutí zainteresovaných aktérů - konkrétně rodičů (romských a neromských), vyučujících a vedení školy -, které zasazujeme do strukturního kontextu etnických a socioekonomických nerovností. Věnujeme pozornost dopadům takovéto nové konstelace ve složení žákovské populace na měnící se status škol. Zároveň zkoumáme percepci daných změn na vybraných školách samotnými vyučujícími, včetně reflexe jejich vlastního postavení - a sledujeme tedy reprodukci strukturálního statu quo.

Přestože námi popisovaný fenomén odkazuje na jevy zmapované za oceánem před téměř padesáti lety (Coleman, 1966), v kontextu České republiky (Bittnerová, Doubek, \& Levínská, 2011) i v širším evropském kontextu (Denessena, Driessenaa, \& Sleegers, 2005) se jedná o téma relativně nové a je mu věnována poslední dobou značná pozornost. Tento text vznáší zásadní otázky týkající se fungování určitého typu škol - od každodenního učení se (žáci), vyučování (učitelé) až po strukturální pohled na ekonomické fungování těchto škol, jejich symbolickou pozici na mapě základních škol, jakož i otázky přesahující budovy těchto škol směřující k připravenosti vyučujících vyučovat na „cikánských školách“.

\section{Výzkum procesu etnické homogenizace škol}

Tato stat' vychází z téměř jednoletého etnografického výzkumu dvou škol nacházejících se v blízkosti sociálně vyloučené lokality, definované Radou vlády ČR pro záležitosti romské komunity (Kašparová, Ripka, \& Sidiropulu Janků, 2008). Výzkum na školách probíhal v období, kdy se obě školy vyrovnávaly s následky sloučení a dalšími proměnami ve složení žáků. Tyto školy jsme během několika měsíců pravidelně navštěvovaly, pozorovaly jsme průběh výuky romských dětí, uskutečnily jsme několik kvalitativních rozhovorů a průběžně analyzovaly interní data škol - např. statistiky o absolventech a absolventkách -, které jsou součástí výročních zpráv. Následujíc

2 Název města i škol (viz dále) byl změněn, aby byla zaručena anonymita. 
logiku etnografického výzkumu jsme se tedy neomezovaly pouze na jednu techniku sběru dat, ale usilovaly jsme o diverzitu empirického základu s cílem „zjistit mnoho o málu“ (Hammersley \& Atkinson, 1995).

Prvním zdrojem empirických dat tedy byla v tomto výzkumu pozorování ve vyloučené lokalitě, ve školní budově a ve třídách, která jsme realizovaly opakovaně v průběhu května až června a září až listopadu. Vyloučená lokalita byla jasně prostorově specifikována Radou vlády ČR pro záležitosti romské komunity. Jedná se o neveliký prostor o cca 2 km čtverečních, vymezený konkrétními ulicemi a dominantami města. Dlouhodobé pozorování prostorového uspořádání i sociálních interakcí v lokalitě, spojené s analýzou psaných materiálů (historizující literatury i aktuálních webových i tištěných vyhlášek a nařizení místního zastupitelstva) a rozhovorů s pracovníky neziskového sektoru vyústilo v etnografický popis lokality, kterému je věnována druhá kapitola této stati. V rámci lokality, resp. $v$ její bezprostřední blízkosti, se rovněž nachází dvě základní školy, které byly předmětem našeho užšího zkoumání. Pozorování ve školní třídě vyžaduje velkou časovou investici a je podle Jarkovské (2013) velice vhodnou technikou pro výzkum dětí (ve škole). Tato pozorování nám poskytla informace o každodenní dynamice na školách - o tom, jak probíhá výuka, jaká témata se řeší (mimo výukovou látku) a jak funguje třída jako kolektiv. Vedle pozorování ve školách jsme také měly možnost účastnit se dvou mimoškolních aktivit (výletů pořádaných neziskovou organizací). Během pozorování jsme se soustředily především na interakce vyučující-žák(yně), ale také na interakce mezi dětmi. Neodmyslitelnou součástí pak také byla reflexe naší pozice vzhledem k dětem, které nás považovaly za „cizí gádžovky“ a snažily se vysvětlit si naši pozici v jejich tř́dě. Pozorování probíhala také před školou $v$ době, kdy děti ráno přicházely, což nám umožnilo sledovat mimo jiné to, kdo děti vodí do školy. Vzhledem k charakteru této studie nám data získaná během pozorování slouží spíše pro kontextualizaci celého fenoménu. Předkládaná studie se tedy zakládá především na dvou technikách, a to rozhovorech a analýze psaných materiálů školy.

Romizace je dlouhodobým procesem, a proto jsou zásadním zdrojem dat hloubkové rozhovory. Těch jsme uskutečnily dohromady třicet s různými aktéry. Mezi nimi byli představitelé škol (ředitelé a jejich zástupci, celkem 4 informátoři - opakované rozhovory), zaměstnanci škol (vyučující a pedagogičtí asistenti, celkem 12) a zaměstnanci neziskových organizací zaměřených na volnočasové aktivity a působících $v$ této geografické oblasti (celkem 4 rozhovory). S těmito aktéry jsme uskutečnily formální rozhovory, které jsme s jejich souhlasem nahrály na diktafon a následně přepsaly. Během pozorování jsme také uskutečnily kratší neformální rozhovory s dětmi a jejich rodiči (celkem 10 rozhovorů). Vzhledem k povaze celého procesu homogenizace se formální rozhovory věnovaly nejen současnému statu quo na školách, ale také retrospektivním interpretacím toho, jak k současnému stavu došlo. Tyto časové rekonstrukce pro nás byly klíčovým zdrojem zvýznamňování daných událostí a akcentů přisuzovaných samotnými informátory, které jsou v kvalitativním výzkumu stěžejní.

Dynamický pohled na kvantitativní proměny na obou základních školách nám poskytla analýza psaných materiálů školy. K těm patřily jednak ročenky, které jsou 
82 veřejným dokumentem nacházejícím se na webových portálech jednotlivých škol, ale také interní neprezentované dokumenty školy. Tyto materiály nám poskytly širší kontext a kvantitativní data týkající se proměn v minulých letech (především o odlivu žáků). Zároveň nám také poskytly zdroje dat o sebe-prezentaci škol (jaké události na internetových stránkách a v ročenkách školy zdůrazňují, jak prezentují svou jedinečnost na vzdělávacím trhu apod.).

Jak zdůrazňuje řada autorů, analýza dat je vždy základní součástí jejich sběru (Riesman, 2008; Hammersley \& Atkinson, 1995). Ezzy v této souvislosti uvádí, že „výzkumníci dělají v průběhu sběru dat řadu rozhodnutí, která jsou nedílnou součástí toho, jak jsou a budou data analyzována - jedná se např. o volby toho, o čem a s kým mluvit, na co se ptát, na co se zaměřit a co ignorovat. Tyto volby jsou produktem výzkumníkovy rozvíjející se interpretace studovaných fenoménư“ (2002, s. 73). Také naše analýza prostupovala celým sběrem dat a směřovala následné kroky ve výzkumu. Interpretace předkládané v této stati saturují kolem klíčové otázky „jak dochází k etnické homogenizaci škol a jaké dopady tato homogenizace má na podobu školy?“. Abychom odpověděly na tuto otázku, soustředily jsme se na významy a interpretace tohoto procesu samotnými aktéry. Sledovaly jsme, jak aktéři hovoři o minulých i současných událostech a jak sami zvýznamňují ty které rysy a aspekty daného procesu. $V$ předkládané stati zasazujeme tyto emické výpovědi do širšího sociokulturního a geografického kontextu, abychom poukázaly na obecnější vzorce tohoto procesu. Prezentujeme zde tedy př́padovou studii dvou lokálních základních škol, která si neklade nároky na generalizovatelnost. Nicméně se domníváme, že k podobným procesům, $\mathrm{k}$ jakým docházelo a dochází v námi studované lokalitě, mưže docházet také $v$ jiných lokalitách, které nesou společné rysy vyloučené lokality. Přesah prezentovaných prípadových studií tak spočivá v analýze styčných bodů mezi mikrovýpověd'mi aktérů a makrostrukturálními fakty.

$\checkmark$ závěru této části považujeme za důležité alespoň v krátkosti reflektovat nejdůležitější terminologii, se kterou v textu pracujeme. Jak upozorňují četné př́ílady z romistické i sociálně-antropologické literatury, Romové v České republice netvoři kulturně, historicky ani sociálně homogenní skupinu, přesto jsou takto nazíráni veřejností i politickým diskurzem (Raichová, 2001; Janků, 2003; Kašparová, 2014). Jakkoli se mohou sociální vědy v souvislosti s Romy přít o účinnost užití etnicity coby užitečné deskriptivní kategorie (za všechny viz debata v Lidových novinách - Barša, 2005; Elšík, 2005; Jakoubek, 2005), mediální i politický jazyk dokládá její pevné usazení v každodenní promluvě. Podrobíme-li však etnicitu coby klasifikační kategorii podrobnému zkoumání, zjistíme, že se jedná o kontextuální kvalitu houbovitého charakteru, která podle libosti a nutnosti do sebe nasákne či vyždímá kritéria, jako jsou např. společný jazyk, historie, odlišná pigmentace kůže, sociální status apod. Proto ji mnozí považují z analytického hlediska za kategorii neúčinnou. Tajemství jejího úspěchu a lákavosti pro její používání však spočíá v její podstatě, a tou je klasifikační schopnost tř́dit jednotlivce i skupiny na My a Oni nebo Já a Druhý. Ponechme pro účely tohoto textu stranou debaty spojené $s$ mocí, kterou s sebou přináší př́slušnost ke konkrétní skupině My či Oni (Said, 2008). B. S. Turner (1994) 
předpokládá, že mechanismus vytváření duality Já/Jiný je univerzálním lidským klasifikačním mechanismem. Jedině v tomto smyslu tedy můžeme hovořit o Romech coby homogenní skupině, jejímž protipólem je skupina ne-Romů. Tímto pravidlem se $v$ následujícím textu rídíme i my.

\section{Sociálně vyloučená lokalita a kulturní vylučování}

Barvîrov je velké město, které, podobně jako mnoho jiných měst v České republice, sestěhovalo svoje Romy do jedné lokality. Tento proces probíhal pozvolna od 50 . let minulého století, kdy se část středu města vylidnila díky odsunu bývalého německého i židovského obyvatelstva. Prázdné byty, situované v bezprostřední blízkosti centra, přesto již v industriální zástavbě, byly povětšinou pavlačového typu, malometrážní a $s$ topením na tuhá paliva. Ne-Romové preferovali $v$ té době bydlení na moderních sídlištích, opuštěné byty byly přidělovány ponejvíce Romům, kteří se vrátili po druhé světové válce $z$ koncentračních táborů nebo přicházeli ze Slovenska (at’ již dobrovolně, nebo nuceni $v$ rámci plánovaného socialistického rozptylu cikánského obyvatelstva ${ }^{3}$.

Romové v této lokalitě Barvířova žijí dodnes, její význam pro město se však během posledních 50 let výrazně proměnil. Město se neustále rozrůstá, proto je tato romská lokalita nyní součástí nikoliv předměstí - jak tomu bylo $v 50$. letech minulého století, ale širšího centra, tj. velmi lukrativních pozemků pro růst a rozvoj obchodu, služeb i bydlení. Společenské proměny po roce 1989 a s nimi související restituční zákony znamenaly $v$ mnoha prípadech změnu majitele nemovitostí a následné stěhování bývalých nájemníků, povětšinou však v rámci samotné lokality, pouze do horších podmínek (nebytové prostory, sestěhování $k$ rodině, menší byty). Přes veškeré změny, které se zde za posledních patnáct let udály, zưstává lokalita nadále tzv. romským ghettem Barviřova, $v$ neposlední řadě proto, že ostatní části města nejsou ochotné př́padné nové nájemníky mezi sebe pustit. ${ }^{4}$

Velmi zajímavě se lokalita jeví, porovnáme-li její urbanismus a krajinnou architekturu s jinými částmi města. Převládající barvou je zde šedá. Je to barva většiny domů, chodníků i veřejných prostorů. Přestože se jedná o lokalitu cca dva kilometry čtvereční, nenajdeme zde jediný park či jinou veřejnou zeleň, s výjimkou několika stromů. Chybí zde dětské hřřště a jiný základní městský mobiliář, jako jsou lavičky k odpočinku či veřejné odpadkové koše. Místo rovněž postrádá přirozené centrum, veřejný shromažd'ovací prostor typu náměstí, kde by se lidé mohli setkávat. Dospělí i děti $v$ této lokalitě tedy tráví svůj čas na chodnících a ulicích, mezi auty a procházejícími lidmi. Alternativou jsou nízkoprahové kluby neziskových organizací, které se $v$ této lokalitě koncentrují, podobně jako prodejny se zbožím druhé jakosti (second-

3 Viz např. Davidová (1995).

4 Romové obývající tuto část města patři ekonomicky do nejnižší vrstvy obyvatelstva, jsou tedy výhradně nájemníky, závislými na pronajímateli. Nejedná se zde o rodiny movitější, které disponují dostatkem prostředků ke koupi vlastního bydlení. 
84 handy, zlevněné potraviny, zastavárny) a v neposlední řadě také herny, nonstop-bary a restaurační zařízení nižších cenových kategorií.

Lidé zde žijící jsou většinou Romové, respektive ta část barviřovských Romů, která patří do ekonomicky nejslabší skupiny obyvatel města. Aplikace jiných kritérií podobnosti je velmi problematická, nebot' místní obyvatelé pochází z různých romských skupin a rodin. Nepojí je ani společný jazyk (ne všichni hovoří romsky, nebo naopak česky), náboženská orientace či tmelící autorita. Řada romských rodin žije v Barviŕrově také mimo tuto lokalitu a jejich děti navštěvují své spádové školy jinde ve městě. Problémy jejich integrace jsou z pohledu učitelů těchto škol minimální. Odlišná je však zkušenost spádových škol, které pưsobí v romské lokalitě, jak bude ukázáno níže. Otázkou zůstává, do jaké míry je tedy kategorie etnicity relevantní pro generalizace sociálního vyloučení. Neméně důležité se totiž v kontextu Barviřova jeví sociální vyloučení vázané ke konkrétní lokalitě, tj. prostorové koncentraci Romů, homogenizované svou nízkou kupní silou a ekonomických potenciálem.

Školy, které jsou součástí naší př́padové studie, leží v tomto „ghettu“, v sociálně vyloučené lokalitě5, která je specifickým socioekonomickým a sociokulturním kontextem. Proces vzdělávání a jeho redistribuci je proto nutné chápat $v$ této lokalitě především prizmatem sociálního vyloučení. Petr Mareš a Tomáš Sirovátka (2008, s. 273) definují sociální vyloučení jako:

proces, který jedince zbavuje práv, ale i povinností, jež jsou spojena s jeho členstvím ve společnosti. Chudoba pak již není zdaleka považována za jedinou přičinu sociálního vyloučení a hovoři se o pluralizaci nerovností. Za sociálně vyloučené ze společnosti jsou považováni ti, kdo z důvodů, jež jsou mimo jejich kontrolu, nemohou participovat na normálních aktivitách svých spoluobčanů.

Definice sociálního vyloučení zahrnuje různé dimenze - od ekonomického, sociálního, symbolického až po kulturní. Pokud přemýšlíme o vzdělávání v kontextu sociálně vyloučených lokalit, přemýšlíme v termínech kulturního vyloučení. To Mareš (2000, s. 287) definuje jako „odepření práva jedince či kolektivity participovat na kultuře společnosti a sdílet její kulturní kapitál, vzdělanost i hodnoty“. Proces kulturního vylučování zahrnuje omezování přistupu ke vzdělání a vyloučení z možnosti sdílet kulturní kapitál společnosti (viz Bourdieu, 1998). To může mít podle Člověka $v$ tísni vnější a vnitřní příčiny - mezi ty vnější patří zařazování dětí do praktických nebo romských škol, $k$ vnitřním pak můžeme řadit např. nízké vzdělání rodičů (Brož, Kintlová, \& Toušek, 2007). Koncept sociální exkluze do jisté míry nahrazuje starší koncept chudoby (Mareš, 2006) a znamená přesun akcentů ve studování nerovností. Slovy sociologa Anthonyho Giddense (1998, s. 104, citováno in Mareš, 2006, s. 6), „koncept exkluze se nevztahuje k stupňování nerovností, ale k mechanismům, které mají za následek oddělování určitých skupin od hlavního proudu společnosti“. Výzkum sociálního vylučování je charakteristický analytickým přesunem zájmu od vertikálních nerovností (založených na distinkci nahoře versus dole) k horizontálním

5 Lokalita byla takto oficiálně charakterizovaná ve studii MPSV 2006: Analýza sociálně vyloučených romských lokalit a absorpční kapacity subjektů pưsobících v této oblasti. 
nerovnostem, jejichž hlavní dichotomií je uvnitř versus vně (Mareš, 2006; Mareš \&

Sirovátka, 2008). Studium kulturního vylučování (vylučování ve vzdělávání) je tedy studiem toho, jak jsou určité skupiny jednotlivců odsouvány mimo hlavní proud a vydělovány ze společnosti/z mainstreamového vzdělávacího systému.

Lokace těchto škol v sociálně vyloučené lokalitě je klíčovým faktem, který ovlivňuje povahu vzdělávání. Jinými slovy, jak ukázali Nekorjak, Souralová a Vomastková (2011), je to bydliště v sociálně vyloučené lokalitě, a s ním související specifický socioekonomický status, soubor životních příležitostí a rolových modelů, spiše než etnicita obyvatel per se, které ovlivňuje vzdělávací strategie a možnosti na dosažení vzdělání daných jedinců. Prostorové umístění škol a etnické složení lokality výrazně ovlivňuje podobu vzdělávání. Autor a autorky dále upozorňují na roli principu spádovosti škol a dělení na školské obvody. Tento princip je definován školským zákonem (561/2004 Sb.), kde jsou povinnosti škol vymezeny v (§ 36) odst. 5 a 7 následovně:

Žák plní povinnou školní docházku $\vee$ základní škole zřízené obcí nebo svazkem obcí se sídlem ve školském obvodu (\$ 178 odst. 2 ), v němž má žák místo trvalého pobytu (dále jen „spádová škola“), pokud zákonný zástupce nezvolí pro žáka jinou než spádovou školu (...).

Ředitel spádové školy je povinen přednostně přijmout žáky s místem trvalého pobytu $v$ příslušném školském obvodu a žáky umístěné $v$ tomto obvodu ve školském zařízení pro výkon ústavní výchovy, ochranné výchovy nebo ve školském zařizení pro preventivně výchovnou péči, a to do výše povoleného počtu žáků uvedené ve školském rejstříku.

Fakt, že škola musí přijmout žáka spádově náležejícího a zároveň nemusí přijmout nenáležejícího, dopadá jak na strategie rodičů při výběru školy, tak na strategie škol a jejich zástupců při výběru (tj. přijetí, či odmítnutí) žákyň a žáků. Zároveň vytváŕí kompetitivní prostředí mezi školami, které se mohou profilovat tak, aby přilákaly více žákyň a žáků (více viz Nekorjak et al., 2011). Podobně jako pozitivní reputace (úspěšnost $v$ přijímacích zkouškách na střední školy, profil vzdělání - zaměřenost na určité disciplíny jako sport, matematika, cizí jazyky atd.) funguje také reputace negativní - a počet romských dětí pocházejících ze sociálně vyloučené lokality je jednou z nich. Negativní reputace je tak formována na průsečíku tří faktorů: exkludujícího potenciálu bydliště, ekonomického statusu rodin a romství.

\section{Rodiče jednající a strategizující: chytřejší škola, pomalejší škola a cikánská škola}

Na pozadí těchto faktorů se $v$ námi studované lokalitě odehrála zásadní událost, která na dlouhou dobu ovlivnila podobu vzdělávání romských i ne-romských dětí. Popis událostí výraznou měrou připomíná situaci v USA v 60 . letech, které ve své zprávě popsal J. S. Coleman (1966), známou dnes jako white flight. Coleman se ve své studii vyjadřuje $\mathrm{k}$ pokusům americké vlády o desegregaci amerického školství a dochází k závěrưm, že tato desegregace mưže být úspěšná a př́nosná pouze tehdy, bude-li ve 
86 třídách vyšší procento bílých žáků než Afroameričanů. $V$ opačném př́padě bílí rodiče své děti ze školy odhlásí a stane se z ní nově škola segregovaná. Podobný vývoj zaznamenaly i školy v Barvírově. I zde, podobně jako $v 60$. letech minulého století v USA, se jednalo o strukturální zásah a politické rozhodnutí zřizovatele (vlády/státu).

Před klíčovým bodem zlomu fungovaly v lokalitě dvě spádové školy, toho času „romské“ základní školy (lokalita byla rozdělena v podstatě na poloviny) a blízko jejich hranic další dvě základní školy (ne-romské a určené pro relativně bohaté rodiny obývající oblast přiléhající k lokalitě). Nazývejme je škola Červená a Zelená (obě mimo lokalitu) a Žlutá a Modrá (spádové pro lokalitu). Pak ale došlo ke sloučení dvou dvojic škol: ze škol Červená a Žlutá se nově stala škola Oranžová obývající budovu Červená a budovu Žlutá; ze škol Zelená a Modrá se stala škola Tyrkysová nacházející se ve dvou budovách - Zelené a Modré (viz obrázek 1). A tak se najednou školy, které byly v bezprostřední blízkosti (školu Červenou a Žlutou dělilo asi 100 metrů, Zelenou a Modrou asi 500 metrů), ale symbolicky je dělila tlustá neviditelná zed' (romské děti na Červenou ani Zelenou školu nechodily, a pokud ano, byly „odporoučeny“ na svou spádovou školu, tedy Žlutou a Modrou), staly součástí dvou komplexů, dvou různých spádových obvodů zahrnujících jak sociálně vyloučenou lokalitu, tak lukrativní rezidenční čtvrt'.
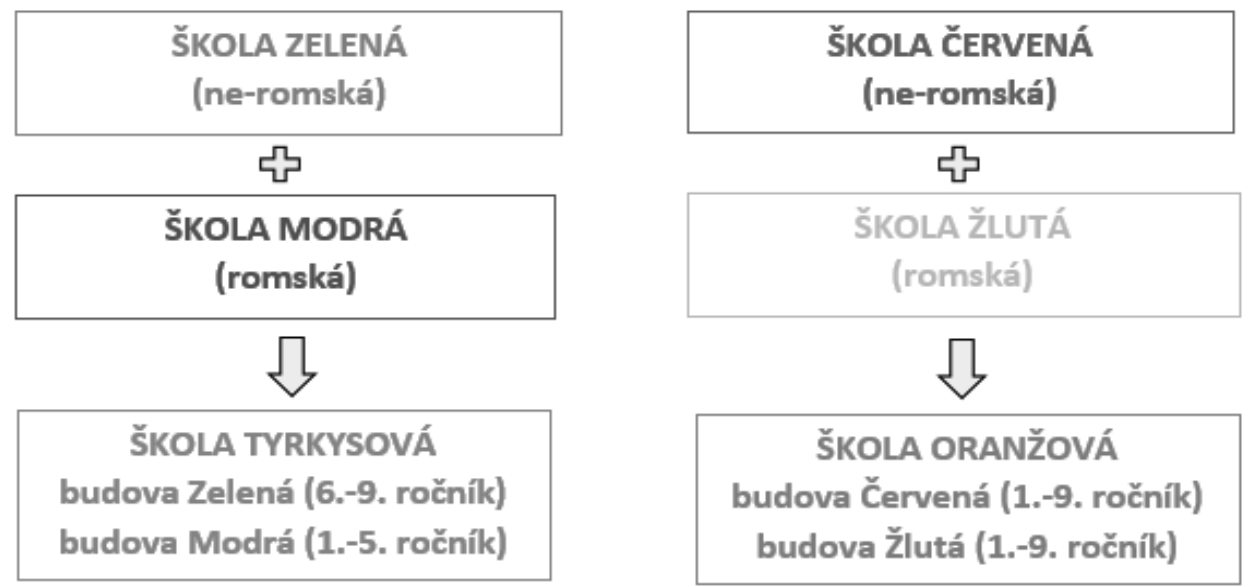

Obrázek 1 Sloučení škol

Každá z nově ustavených škol přišla s jinou strategií využití dvou budov. Zatímco škola Oranžová ponechala v obou budovách ročníky od 1. do 9. třídy, škola Tyrkysová zvolila jinou taktiku: budova Modrá (dřive romská) měla obstarat první stupeň, budova Zelená pak stupeň druhý. $V$ prvním př́padě to $v$ praxi znamenalo to, že fakticky mohlo pokračovat dělení na převážně ne-romskou a romskou školu, když budova žlutá zůstala nadále $v$ mentální mapě zapsána jako romská škola. Naproti tomu na budově Červená mohla být započata integrační strategie propagovaná tehdejším vedením; ta $v$ praxi znamenala integraci 3-4 romských dětí do ne-romských tř́íd. Tento počet 
měl zamezit romizaci tříd a zároveň měl umožnit „nenásilný“ kontakt romského a ne-romského žactva. Vyučující zároveň měli „pendlovat“ mezi oběma budovami. Ve druhém případě byla situace mnohem více „radikální“ ve smyslu nabourání zažitých symbolických hranic a oné výše zmíněné skleněné zdi. Konkrétně odlišení budov podle ročníků značilo, že děti žijící mimo lokalitu spádově náležející pod školu Tyrkysová měly docházet do středu lokality a tam si odchodit první až pátý ročník své devítileté povinné školní docházky. Zároveň pak děti žijící v lokalitě by se z ní dostaly ven v momentě, kdy by začaly navštěvovat šestý až devátý ročník umístěný v budově Zelená.

Interpretováno v termínech „prríležitostí“ můžeme říci, že nově vzniknuvší škola Oranžová přinesla prríležitost $\mathrm{k}$ integraci začleněním několika jednotlivců do ne-romského kolektivu (v souladu s poučením z hrozby white flight) a cirkulací vyučujících mezi oběma budovami. Vedle ní škola Tyrkysová nabídla příležitost smazání rozdílů a natáhnutí ne-romských dětí do lokality a romských mimo ni, a tím smísení obou do té doby oddělených skupin pod jednu střechu. K ničemu takovému však nakonec nedošlo, protože ani jedna vize nepočítala s ráznými reakcemi rodičů. Kam tedy nová konstelace základního vzdělávání v lokalitě vedla? Než odpovíme na tuto otázku, je třeba zdůraznit, že i když jedním z hlavních rysů sociálního vyloučení je to, že sociálně vyloučení mají určité věci a procesy „mimo svou kontrolu“ (viz výše), neznamená to, že jsou jen pasivními obět'mi. Spíše než to, metaforicky řečeno, jsou hráči, kteří se aktivně pohybují na hracím poli, i když možnosti jejich tahů jsou vzhledem k širším strukturním omezením limitované.

Situace na škole Tyrkysová vypadala následovně, jak popisuje jedna z jejích tehdejších zaměstnankyň: Ihned po sloučení došlo k té změně, že odešlo 200 ne-romských dětí. A bylo to dáno tím, že tyto rodiny žijí v této lokalitě, spádově sem patří, ale nikdy by své dítě, ne-romské dítě, na této škole nenechali. Zưstalo tu pár těchto dětí, myslím si, že problémy ve škole nebyly, naopak. My jako škola se snažíme získat ne-romské děti i nadále, ale nedaři se nám to. Mám asi dvě třídy spádově patřicích ne-romských dětí na ZŠ Růžová [škola mimo lokalitu navštěvována spádovými neromskými dětmi], no a potom tady na okolních školách. Takže děti tady jsou, ale do této školy nepůjdou, protože je rodiče nepřivedou k zápisu.

Odliv 200 dětí z této školy znamenal snížení počtu dětí na dvě třetiny počtu před sloučením. Odliv ne-romských dětí byl doprovázen odlivem vyučujících učících původně na ZŠ Zelené, kteři údajně odmítli učit romské děti a/nebo pod novým vedením školy. Na škole tehdy zůstalo jen pár ne-romských dětí, povětšinou těch, co navštěvovaly poslední ročníky a jejich rodiče je nechali „dochodit“ na stávající škole. Ročníky prvního stupně, který byl umístěn v budově Zelená v centru lokality, se přes prázdniny homogenizovaly a jejich žactvo tvořily pouze romské děti. Zajímavější situace však přetrvávala na mateřských školách spadajících pod nově vzniklou ZŠ Tyrkysovou. Tyto mateřské školy jsou dlouhodobě navštěvovány hlavně ne-romskými dětmi (kromě předškolního ročníku povinného pro všechny). Ačkoli uprostřed sociálně vyloučené lokality, MŠ v budově Modrá se těší návštěvnosti ne-romských dětí, které však nastupují svou povinnou školní docházku na školách mimo lokalitu, tedy nepokračují na ZŠ Tyrkysové. Tento příklad přechodu mezi předškolním a školním vzděláváním a jeho 
88 etnickým složením ukazuje diskrepanci mezi tím, za jakých okolností jsou ne-romští rodiče ochotni „skousnout“ školu v lokalitě ( $v$ kontextu, kdy poptávka po místech v MŠ převyšuje nabídku) a kdy už ne ( $v$ kontextu „boje o žáka“ na základních školách, které mohou rodiče $v$ důsledku nastavení principu spádovosti libovolně volit).

$K$ podobné situaci došlo na ZŠ Oranžové, která zaznamenala hromadný odchod 140 ne-romských dětí, a to ze stejného důvodu jako na ZŠ Tyrkysové. Zde byl odchod poněkud tlumen zachováním dvou budov, jak bylo uvedeno výše. Oproti ZŠ Tyrkysové na této škole však došlo také k odchodu romských dětí, jejichž rodiče měli strach, aby jejich děti na „chytřejší škole“ stíhaly. Zde byla pro ZŠ Oranžovou do jisté míry výhoda umístění prvního stupně v lokalitě, která pravděpodobně fungovala pro rodiče jako jistota. Jak uvedla jedna z našich informátorek, kterou jsme oslovily před budovou Modrá, kam odváděla svého syna:

Tady kousek je dalši škola, ale tam jsou moc rychlí, na Oranžové. Tam je to „dneska naučíš, zítra zkouším“. Tady jdou na ně pomaleji, já jsem tady spokojená.

Fakt, že si škola Oranžová udržela relativně vysoký počet ne-romských dětí, zvyšoval v lokalitě její prestiž oproti škole Tyrkysové. Analogicky k tomu byla chápana romskými rodiči jako „těžši“ nebo „chytřejší“ škola, a zaznamenala také v kýžený rok odchod menšího počtu romských dětí. Jejich rodiče, jak je patrné z úryvku s oslovenou maminkou, se obávali, aby jejich děti na „chytřejší škole“ stíhaly. Relativně dramatická situace na této škole však pokračovala dále, a to v momentě, kdy se do nového školního roku zapsal poměrně vysoký počet romských dětí, jejichž rodiče chtěli, aby navštěvovaly budovu Červená (kam do té doby byly integrovány 3-4 děti na třídu). Když se pak v červnu předcházejícímu novému školnímu roku konala schůzka rodičů, ne-romští rodiče byli překvapeni vysokým počtem romských žáků a žákyň. Jejich překvapení pak vyústilo $v$ odchod ne-romských dětí, kdy ze tří tříd prvního ročníku na celé ZŠ Oranžové byly dvě romské (jeden tradičně v budově žlutá, druhý nově v budově Červená) a jednu tř́du v budově Červená navštěvovaly tři romské děti. To se však nelíbilo ani romským rodičům (pocházejícím z lokality), kteří 1. zárí dovedli své děti do školy. Stěžovali si tehdejšímu vedení na to, že tř́ídy jsou romské. To popsala jedna ze zaměstnankyň: Ve chvíli, kdy se tady potkali rodiče prvního záríi, opět šilenej řev, ale tentokrát romských rodičů, kteři tady chodili řvát na paní učitelky, na mě, málem na ministra školství, který tady prvního zárí byl, jak je to šilený, jak my jsme ty děti rozdělovali, že $v$ jedné tř́idě máme více romských žáků a $v$ jedné miň. Ale $v$ podstatě když ti ne-romští odešli už $v$ červnu a přes prázdniny a dalši 4 odešli $\checkmark$ zárí, tak se nedá nic dělat, zůstali romští. A nastala patová situace, kdy oni řvou, jak jsou Romové s Romama, a oni přece $k$ těm Romům ty svý děti nedají.

Události, které jsme výše popsaly, poukazují na několik důležitých faktů týkajících se procesu homogenizace (etnizace) škol $v$ České republice. Tato zjištění musí být čtena $v$ kontextu města, ve kterém se reprodukuje nízký socioekonomický status určité lokality a jejich obyvatel, v kontextu současného nastavení fungování škol (viz zmíněný zákon o spádovosti) a s ohledem na každodenní rozhodování zainteresovaných aktérů.

Za prvé, analýza procesu homogenizace ukazuje, jak je homogenizace daných škol provázána s jejich stigmatizací. Označení „cikánská škola“ s sebou nese negativ- 
ní konotace, které jsou odvozeny jednak od umístění škol na „špatné adrese“6 (role sociálně vyloučené lokality), jednak etnickým složením žactva. V prvém př́padě „ک̌patná adresa“ přechází k povaze školy samotné, která se stává jejím ztělesněním. Jak ukázala na př́kladu Brna Annett Steinführerová (2003), jedinci negativně hodnotí ty části města, ve kterých jsou koncentrováni právě Romové. „Špatná adresa“ je pak místem, kam se jen tak nechodí, a pokud se škola nachází v její blízkosti nebo přímo na ní, mưže se stát vymístěným místem, tj. místem, které nefiguruje v mentální mapě jedinců-rodičů dětí školou povinných jako „navštěvovatelné“. Právě z tohoto důvodu se poloha školy v blízkosti lokality spolu se současným nastavením „vzdělávacích trhư“ (viz Nekorjak, Souralová, \& Vomastková, 2011) snáší jako Damoklův meč nad školami, které nevyhnutelně čelí odchodu ne-romských a př́livu romských dětí.

Ve druhém př́padě je to stigma spojené s romstvím (abychom použily Goffmanův koncept; Goffman, 2003), které se stává stigmatem školy. Škola je navštěvována obyvateli sociálně vyloučené lokality, Romy či „sociálními případy“. Toto stigma se pak vepisuje nejen do budovy, ale také do jejích zaměstnanců, kteří se $z$ učitelů a učitelek stávají těmi, kdo „učí na špatné škole“ (viz níže). Takovou reflexi vlastního působení nám $v$ rozhovoru zprostředkovala jedna ze zaměstnankyň školy Tyrkysová: Já jsem si to potvrdila $v$ té Praze, i v tom Chánově, že i pro mě jako pro ředitelku, nejsem rovnocenná partnerka mezi řediteli, já jsem prostě z té cikánské školy.

$\mathrm{Na}$ tomto príkladu tak pozorujeme symbolické vylučování škol v kontextu celorepublikové mapy ZŠ a vznik neoficiální, avšak sdílené, hierarchizace škol odvíjející se od etnického a/nebo socioekonomického statusu žákyň a žáků, kteří ji navštěvují, a předpokládané nižší kvality výuky.

Za druhé, dalším stěžejním trendem, který tyto události koncentrovaně ukazují, je past kulturního vyloučení a vylučování. Vzdělání a procesy vzdělávání, které mají být indikátorem integrace do společnosti, jsou výrazně ovlivňovány samotnými aktéry a jejich volbami. Jak ukázaly události kolem sloučení škol, rodiče aktivně hledají a zvažují své možnosti umístění dětí. Kromě toho situace na ZŠ Oranžové demonstruje, že nejen ne-romští rodiče taktizují a posílají své děti do škol s ohledem na složení jejich žáků, ale to samé dělají také někteří romští rodiče. $V$ návaznosti na výše uvedené je třeba říci, že jak pro ne-romské, tak pro romské rodiče je složení žáků ve třídě jedním z hlavních rysů kvality výuky - zatímco pro ne-romské rodiče je počet romských dětí indikátorem nižší kvality, pro romské je počet ne-romských dětí ukazatelem vyšší kvality. Sledované situace tak naznačují, že i když určitý typ rodičů projeví snahu vymanit se z kulturního vyloučení (posláním svých dětí na školu, kde je zastoupení romských dětí menší), setkává se tato snaha s neúspěchem (automatickou reakcí je odchod ne-romských dětí). To směřuje k prohloubení vyloučení a romizaci další školy. Pokud tedy nedochází k jakékoli regulaci prosazující rovnoměrné rozložení romských dětí do škol (viz Obrovská, 2014), odehrává se proces

6 Považujeme za důležité zmínit $v$ tomto místě, že jakkoliv se nám jeví jako zajímavé a přínosné sledovat mechanismy, které přispívají k vytváření povědomí o „špatné adrese“ a na ní následně navázané povědomí o „špatné škole“, z kapacitních důvodů se jim v této stati nevěnujeme. Pro širši popis procesu sociálního vylučování v souvislosti se strukturálními mechanismy (viz Kašparová, Ripka, \& Sidiropulu Janků, 2008). 
90 homogenizace mimo možnosti zásahu vycházejícího ze škol samotných. Jsou to tedy především hlavně rodiče - romští i ne-romští, kteři svými rozhodnutími o zápisu svých dětí na ZŠ rozdávají karty, s nimiž je pak nuceno hrát nejen vedení škol, ale také vyučující. Na jejich situaci se zaměříme v následující části statě.

\section{Učit na cikánské škole: reflexe vzdělávacího procesu vyučujícími}

Stigmatizace lokality i základních škol v ní ovlivnila vedle jednání rodičů i rozhodování učitelů. Po personální stránce prodělaly v době fúze obě barvířovské školy velké změny. Pedagogický sbor se po sloučení z větší části zcela obměnil. Neromští rodiče i učitelé předpokládali v romské škole nižší kvalitu výuky: Já jsem učila na Zelené škole, takže když došlo ke sloučení, tak jsem si ř́kala, že kvůli tomu jsem teda tak dlouho nestudovala, že to nemám zapotřebí (učit výlučně romské děti, poznámka autorek). Ale zůstala jsem, a ted' jsem tady spokojená, kdo to nezažije, nepochopí (učitelka, ZŠ Tyrkysová).

Ačkoliv nepředpokládáme, že učitelství je v naší společnosti profese, kterou lidé vykonávají „pro peníze“, odlišné platební podmínky na různých typech škol, jakož i extrakurikulární aktivity, kterými se učitelé zabývají nad rámec své běžné praxe, zcela jistě hrají při rozhodování o tom, kde, jak a koho učit, důležitou roli: Já si cením tady třeba sboru, protože tady každý nevydrži, nechce učit na romské škole, a zas mám problémy, nemám na platy učitelů. Dneska jdu jednat na úřady, abychom mohli žít jako normální běžná základní škola, protože nás berou jako běžnou základní školu, ale bohužel pokud ty romské děti tady jsou nakumulovány tak je to trochu jiné. (...) Strukturální fondy... my jsme si na jeden sáhli, ale za cenu, že zástupce leze po stěně, on to dělá, on je na to opravdu výborný, ale zas některé věci tady stojí, které my prostě už nezvládáme. My bychom rádi dělali, ale mě přijde, že už je všechno problém... my tu budoucí generace vychováváme, učíme, suplujeme rodinu a na to peníze nejsou (ředitelka, Zš Tyrkysová).

Úryvek z rozhovoru s ředitelkou školy Tyrkysová představuje výzvu v promýšlení minimálně dvou aspektů spádového modelu školství: 1. způsobu standardního financování základních škol a 2 . role a postavení učitele ve vzdělávání dětí z vyloučených lokalit. Z prostorových důvodů se zde budeme zabývat pouze druhým tématem.

Odborné debaty a výzkumy poukazují na měnící se názory učitelů týkající se změn ve školním vzdělávání, včetně reflexe svého vlastního postavení a přístupu (Straková, Spilková, \& Simonová, 2013). Jako důležitá a přitom nedostatečná se akcentuje spolupráce s rodinou, za kterou škola a učitel přebírá řadu jejích dřivějších funkcí a povinností - od vštěpování základních společenských hodnot po roli př́tele, důvěrníka či jen osoby, se kterou je možné si povídat a která se o dítě zajímá (Bittnerová, Doubek, \& Levínská, 2011). Škola předpokládá, že dítě do ní přichází připraveno; vybaveno dostatečným jazykovým i kulturním kódem, bez kterého je úspěšné absolvování či jen zařazení nepravděpodobné. To se však ne vždy děje a přibývá škol, do 
kterých děti takto připravené a vybavené nepřicházejí. Barviřrovský př́klad dokládá dle našeho mínění dva nedoceněné či zamlčované jevy, které způsobují současnou složitou situaci škol, jako je Oranžová či Tyrkysová. Vzdělávací systém je vystavěn na zkušenostech primární socializace $v$ ne-romské kultuře. Tímto směrem jsou rovněž orientovány vzorce chování, které úspěšné zvládnutí školní docházky vyžadují i podporují. Snaha o zapojení romských dětí do vzdělávacího systému nedoceňuje vliv jejich socializace $v$ nativní kultuře. Místo toho se snaží nabízet alternativu, kterou je zkušenost ne-Romů. Ta je vnímaná jako vhodnější, přínosnější či prostě lepší. Je to projevem mocenské nadřazenosti, o které v souvislosti s definicí Druhého hovoří Said (2008). Absolventské statistiky obou základních škol však dokládají nefunkčnost této cesty: Kam směřují? Já mám zkušenost, že všichni se chtějí vzdělat a všichni se chtějí vyučit. Ale přijdou do deváté třídy, kde ten problém nastane a mají vyplnit přihlášku a oni jak už mě viděli s tou složkou, tak na mě byli zlí. A přitom kdybych je neučila v té osmé tř́dě, tak já bych nevěřila. Když se zeptáte koncem září, kdo $z$ nich studuje, tak nikdo. My máme snad jednoho absolventa, ve kterém máme naději, že odmaturuje (vyučující, zŠ Tyrkysová).

Společnost skrze svou kulturu v průběhu času vypracovala dvojí metodu, jak odlišným způsobem na jedince působit, totiž skrze socializaci a vzdělávání (srovnej Cohen, 2000; Rival 2000). Za socializaci se označuje takové chování, jehož podstatou je vštípení základních kognitivních schémat dané společnosti či kultury. Ta následně umožňují jedinci orientovat se $v$ hodnotách a postojích pojících se $s$ každodenním životem ve společnosti. Socializaci provádí vždy rodina, př́buzní či blízcí lidé a je neodmyslitelně spjata s citovými pouty (pozitivními i negativními). Vzdělávání je vštěpování standardizovaných vědomostí, dovedností a hodnot, které probíhá standardizovaným a stereotypizovaným způsobem a provádí jej osoba, ke které má jedinec citový vztah pouze výjimečně (Cohen, 2000). Prostřednictvím vzdělání se učíme rozumět návykům, myšlení a sociálním hodnotám, které jsou pro většinovou společnost důležité. Tematické učivo (např. př́rodopis, struktura Evropské unie aj.) je jen jeho malou součástí. Mnohem důležitější než ono samotné jsou procesy myšlení a struktura souvislostí, skrze které jsou tato témata žákům vštěpována (Williamson, 1979).

Naráží-li na sebe odlišnosti hodnoty učitelů, coby strážců hodnot předávaných vzdělávacím systémem, a hodnoty rodin, ze kterých jejich žáci pochází (mimo jiné také např́klad proto, že romských dětí je ve tř́dě převaha a učitel se nesetkává s převládajícím pochopením svého chování, svých kulturních vzorců), dochází u učitelů k představám, že výchovná stránka (socializace dětí) jejich působení převládá nad dimenzí vzdělávací. $S$ touto domněnkou se potýkají dle současných studií učitelé napříč současnou společností, bez ohledu na to, zda učí děti romské, či neromské. Zatímco učitelé pečující o děti ne-Romů vysvětlují tento jev obecnými proměnami společnosti a jejích hodnot (srovnej Straková, Spilková, \& Simonová, 2013), učitelé působící na školách $v$ Barvîrově charakterizují podobný jev coby nefunkčnost či odlišnost romské rodiny a její kultury: Tam jsou nejšt'astnější, když se vymyslí akce $v$ sobotu a jede se do divadla, tak to nás budou rodiče opěvovat. Někdy máme pocit, že jenom aby se těch dětí zbavili (vyučující, zš Oranžová). 
Nástrojem vzdělávání a zároveň gatekeeperem vědomostí a kulturního kapitálu je tradičně vyučující - kategorie, do které spadají všichni výchovně pưsobící činitelé - mimo jiné tedy i rodiče a učitelé. Každý dítěti předává to, čemu věří on sám, co je podle něj $v$ životě důležité, co se mu osvědčilo, co zakusil. $V$ prípadě, že to, co je osvědčené a co je pro život hodnotné, je podobné na straně učitele i rodiče, nebývá výchovné působení problematizováno žádným z jeho aktérů, včetně dítěte samotného. Odlišná je však situace ve chvíli, kdy se zkušenosti a víra rodičů liší od zkušeností a víry učitelů:7 Samozřejmě jsou tady děcka prestižních rodičů, kteří už ted' z nich vidí ty právníky a doktory, takže je honí se víc učit, děcka mají různý jazykový kurzy, mají fakticky tři kroky napřed před těmi ostatními dětmi, takže vynikají v té výuce, mají samé jedničky, mají krásné známky. Takže možná kdyby se to zprüměrovalo tak bych řekla, že tady (na Červené) mají lepši průměry než na té Žluté, ale je to dáno právě těmi rodiči, jak je vedou, jak je honí, jak je nutí, ale ti kantoři a ta výuka je stejná. A ted' už záleží, jak ty děti se moc učí a jak ty rodiče jim šlápnou na krk a ti romští rodiče jim na krk moc nešlápnou, aby řekli „uč se, dělej, je to senzační někam se dostaneš“. Ti to neřeknou, zatím co ti neromští to řeknou (ředitelka, Zš Oranžová).

Výše uvedený úryvek z rozhovoru dokládá presumpci odlišné socializace romských a neromských dětí v jejich rodinách, jakož i odlišný hodnotový systém obou kultur. Je $z$ něj rovněž patrné, která $z$ těchto kultur a jejích hodnot je chápána vyučující jako nadřazená té druhé. Vyučující je přesvědčena, že romští rodiče nepovažují dril a disciplínu v souvislosti se školní prípravou za důležitou, což vnímá jako špatné. Rozkol $v$ hodnotovém systému rodičủ a učitelů následně vede $k$ vzájemnému nepochopení, oddělení a složité spolupráci.

$\checkmark$ romské společnosti představuje socializace, tj. důraz na kruh rodiny a příbuzných, jakož i společenská organizace a orientace podle rodinných souřadnic, stále mnohem důležitější roli než ve většinové společnosti. ${ }^{8}$ Rom bez své rodiny nic neznamená, nikým není. Ztrácí ekonomické, politické i sociální vazby (Raichová, 2001). Romští rodiče učí své děti experimentálně, skrze pokus-omyl, tak jako celá řada jiných společností (srov. Rival, 2000; Kašparová, 2014). Od dětství dostávají do rukou předměty denní potřeby, včetně těch, které většinová společnost klasifikuje jako „nevhodné“, bez dozoru rodičů zkoumají své okolí, řeší své konflikty se vším, co k tomu patří. Volí si, co je pro ně v danou chvíli zajímavé a možné, čemu se budou věnovat, jak budou trávit svůj čas. Tato autonomie se rovněž projevuje tím, že je jen malý rozdíl mezi dospělým a dítětem, které má stejná práva (a často i povinnosti) jako dospělý $v$ dané společnosti. To je z pohledu většinové kultury jednoznačně problematický způsob výchovy a socializace, který se snaží tato většinová kultura skrze vzdělání korigovat (Lancy, 2008). Výzkumy napřič světadíly však poukazují na

7 Rozhovory jsme v Barvířově prováděly poté, co došlo ke sloučení „bílé“ a „romské“ školy, tedy poté, co došlo k masivnímu odchodu nejen žáků, ale i učitelů, kteří se s novou realitou odmítali smírit. Předpokládáme proto, že rozhovory poskytovali ti vyučující, kteři mají vưli se aktivně účastnit a ovlivňovat vzdělávání romských dětí v Barviřově a na základě svých zkušeností disponují silnější kulturní senzitivitou.

8 Srovnej Lancy, 2008. 
to, že obdobné snahy končí častěji neúspěchem než opačně (Rival, 2000; Lave, 1990, 1993), nebot' učitel (a filozofie současného vzdělávacího systému, jehož je součástí), který nabourává a zpochybňuje socializaci dítěte, mu nevytváří prostředí dostatečně důvěryhodné $\mathrm{k}$ otevřenému přijímání hodnot propagovaných skrze systém vzdělávání: Tady hlavně člověk musí chtít a to je takový prvotní vklad, protože tady na této škole se nemůžeme realizovat $v$ matematické, chemické olympiádě, tady se můžeme realizovat třeba $v$ těch zájmových věcech (ředitelka, ZŠ Tyrkysová).

Již Colemanưv výzkum (1966) ukázal, že je-li malý počet odlišně primárně socializovaných dětí integrován do společnosti většiny, vykazují tyto děti větší vưli a úspěch při adaptaci na většinové hodnoty. Překročí-li však jejich počet $50 \% \mathrm{z}$ celkového počtu dětí ve třídě, situace je zcela opačná. Zkušenost učitelů, kteří zůstali učit na školách Tyrkysová nebo Oranžová, dokládá, že na podobných školách nevystačí ani s univerzalistickým a standardizovaným pojetím vzdělání, ani s výbornými oborovými znalostmi. Setkávají se s odlišným kulturním a hodnotovým systémem, který testuje ne tak jejich znalosti, jako jejich vlastní víru v tento systém i normy chování s ním spojené. Oproti učitelům v běžných základních školách jsou tak denně konfrontováni nejen s vyjednáváním o obsahu učiva, ale také se svými vlastními hodnotami, normami, vírou a způsobem života. Hledají kompromisní řešení, které by vpustilo do svého světa obě zúčastněné strany.

Role učitele je v procesu vzdělávání nezastupitelná. Barviř́ovská zkušenost odkrývá výzvy, které výuka na romských školách představuje. Vyučující se musí vyrovnat s předpokládanou či skutečnou odlišností svých žáků - a to jak v rovině vědomostní, tak kulturní. Obě barvířovské školy deklarují snahu o překonání těchto rozdílů, ani jedna však nezaznamenala úspěchy, personifikované $v$ absolventech středních škol a učilišt'. Ukazuje se, že rozhodující vliv na způsob života a životní hodnoty barvírovských žáků představuje spíše jejich ukotvení ve vyloučené lokalitě, nativní kultura a primární socializace, než stávající vzdělávací systém. Univerzalistické a standardizované vzdělání a hodnotový systém přesto zůstávají jediným platným vyučovaným kodexem, $v$ jehož jménu jsou odlišné normy a zpưsoby života a chování tlačeny $\mathrm{k}$ asimilaci. Za takových podmínek představuje selhání učitelů především selhávání systému samotného.

\section{Závěrečné poznámky}

V této stati jsme prezentovaly př́padovou studii dvou základních škol, na kterých došlo k etnické homogenizaci složení žactva. Sledovaly jsme proces homogenizace škol jako proces kulturního vylučování a obecně sociálního vylučování. Náš text přichází se čtyřmi základními závěry:

Za prvé, romizace škol je výsledkem individuálních voleb a rozhodnutí vykonávaných jednotlivými aktéry na každodenní rovině. Tuto každodenní rovinu je pak nutno chápat jako zakotvenou ve strukturách třídních a etnických nerovností (jejichž vyjádřením per se je sociálně vyloučená lokalita). Těmito aktéry jsou jednak 
94 rodiče, romští a ne-romští, jednak vyučující. Jsou to romští rodiče, kteří vybírají školu, na kterou zapíšou své dítě podle svých zkušeností (kam oni sami chodili), podle dostupnosti (blízkosti), ale také podle nároků kladených na děti (pro mnohé je vodítkem to, že je škola méně náročná) či podle počtu romských a ne-romských dětí. Neromští rodiče, jak se zdá podle sledu událostí popsaných v této stati, volí školu mimo jiné podle počtu romských dětí a s ním související image, kterou škola má navenek. Vyučující balancují své časové a intelektové investice do př́pravy na budoucí povolání a jejich využití na škole, která stojí nízko na žebříčku symbolického hodnocení. Všechna tato rozhodnutí se odehrávají na pozadí strukturálních podmínek, konkrétně existence lokality spjaté s nižším socioekonomickým statusem, a institucionálních - jako je de iure dělení spádových obvodů. Oba tyto makrofaktory vedou $\mathrm{k}$ relativně prostému, avšak ve svých konsekvencích zásadnímu, závěru, že segregace ve vzdělávání zrcadlí prostorovou segregaci v bydlení.

Za druhé, romizace jde ruku v ruce s hierarchizací škol. „Cikánské školy“ jsou - dle slov jejich zaměstnanců a zaměstnankyň - znevýhodněny nejen finančně, ale také symbolicky. Mají totiž nižší status na žebřičku ž̌s. Tento fakt dopadá také na vyučující, kteří objektivně vykazují řadu aktivit a činností nad rámec svých běžných povinností (např. řešení grantů či nadprůměrná mimoškolní činnost), přesto se oni sami i jejich škola „těši“ ve společnosti svých kolegyň i celé společnosti často pohrdavému př́stupu. Jako by „cikánská“ škola byla pouze méněcennou variantou „skutečného“ světa základního vzdělávání. Místem, kde je málo dětí ve tř́dě (což následně znamená menší platy učitelů), učí se zde pouze základy, protože žáci jsou zde podprůměrní (předpoklad, že učitel zakrní ve svém oboru) a nic po sobě nezanechává, protože děti většinou končí na podpoře bez dalšího vzdělání (skrytá otázka po smyslu takové školy). I zde je patrné, že spiše než individuální rada jednotlivým školám potřebuje společnost systémové řešení.

Za třetí, učitelé hrají důležitou roli v překonávání prostorového a mentálního vyloučení. Naše studie poukazuje na některé strukturální aspekty vzdělávání, které tuto roli učitelům z velké části znesnadňují či dokonce znemožňují. Opomíjení důležitosti socializace $v$ rodné kultuře, jakož i nepřiznaný etnocentrismus vzdělání, působí jako handicap v profesní prípravě pedagogů, kteří se chystají pưsobit v lokalitách, kde žijí romské děti. Kurikulum přijímané univerzalistickým zpưsobem jako dogma blokuje komunikaci a spolupráci mezi vyučujícím a jeho žáky. Vzhledem $\mathrm{k}$ tomu, že sociální vyloučení v České republice dnes není pouze záležitostí Barviřrova, ale týká se čtvrtí ve všech velkých městech naší republiky a někdy i celých okresů či mikroregionů, můžeme $v$ budoucnu očekávat změny. Nestačí angažovaní učitelé s dobrým srdcem, změnu vyžaduje systém sám. 


\section{Literatura}

Analýza sociálně vyloučených romských lokalit a absorpční kapacity subjektů pưsobících v této oblasti. (2006). Praha: Gabal Analysis and Consulting.

Barša, P. (2005). Konec Romů v Česku? Lidové noviny, 15. 1. 2005.

Bauman, Z. (2002). Tekutá modernita. Praha: Mladá fronta.

Bittnerová, D., Doubek, D., \& Levínská, M. (2011). Funkce kulturních modelů ve vzdělávání. Praha: Fakulta humanitních studií UK.

Bourdieu, P. (1984). Distinction: A Social Critique of the Judgment of Taste. Cambridge: Harvard University Press.

Bourdieu, P. (1998). Teorie jednání. Praha: Karolinum.

Bourdieu, P., \& Passeron, J. (1990) Reproduction in Education, Society and Culture. London: SAGE Publications.

Brož, M., Kintlová, P., \& Toušek, L. (2007). Kdo drží Černého Petra? Praha: Člověk v tísni. Dostupné z http://www.clovekvtisni.cz/uploads/file/1364590154-cerny\%20petr.pdf.

Cohen, A.Y. (2000). The Shaping of Men's Minds: Adaptations to Imperatives of Culture. In B. A. U. Levinson (Ed.), Schooling the Symbolic Animal: Social and Cultural Dimensions of Education (s. 83-107). New York: Rowman and Littlefield Publishers, INC.

Coleman, J. S. (1966). Equality of Educational Opportunity. Washington, DC: U.S. Government Printing Office.

Davidová, E. (1995). Cesty Romů. Olomouc: Vydavatelství Univerzity Palackého.

Denessena, E., Driessenaa, G., \& Sleegers, P. (2005) Segregation by choice? A study of groupspecific reasons for group choice. Journal of Education Policy, 20(3), 347-368.

Elšík, V. (2005). Romové, etnicita a radikální konstruktivisté. Literární noviny, 21, 6.

Ezzy, D. (2002). Qualitative Analysis. Practice and Innovation. London: Routledge.

Geertz, C. (2000). The Impact of the Concept of Culture on the Concept of Man. In. B. A. U. Levinson (Ed.), Schooling the Symbolic Animal: Social and Cultural Dimensions of Education (s. 25-30). New York: Rowman and Littlefield Publishers, INC. New York: Rowman and Littlefield Publishers, INC.

Giddens, A. (1998). The Third Way. Cambridge: Polity Press.

Goffman, E. (2003). Stigma. Praha: Sociologické nakladatelství.

Hammersley, M., \& Atkinson, P. (1995). Ethnography. Principles in Practice. London: Routledge. Chapman, K. (1994). The Sociology of Schools. London: Routledge.

Jakoubek, M. (2005). Romisté nedokážou Romy definovat. Lidové noviny, 19. 2. 2005.

Janků, K. (2003). Romové a jiní „skoro-Češi”. Pozice kandidátů sociální inkluze do české společnosti: Otázky sociální inkluze romské komunity. Sociální studia, 10, 115-129.

Jarkovská, L. (2013). Gender před tabulí: Etnografický výzkum genderové reprodukce v každodennosti školní třídy. Praha: Sociologické nakladatelství.

Kašparová, I. (2014). Romská politika - politika romství. Praha: Slon.

Kašparová, I., Ripka, Š., \& Sidiropulu Janků, K. (2008). Dlouhodobý monitoring situace romských komunit v České republice: Moravské lokality. Praha: Rada vlády ČR pro záležitosti romské komunity.

Lancy, D. F. (2008). The Anthropology of Childhood: Cherubs Chattel and Changelings. Cambridge: Cambridge University Press.

Lave, J. (1990). The culture of acquisition and the practice of understanding. In J. W. Stigler, R. Shweder, \& Herdt, G. (Eds.), Cultural Psychology: Essays on Comparative Human Development (s. 309-328). Cambridge: Cambridge University Press.

Lave, J. (1993). The Practice of Learning. In S. Chaiklin \& J. Lave (Eds.), Understanding Practice: Perspectives on Activity and Context (s. 343-374). Cambridge: Cambridge University Press.

Mareš, P. (2006). Faktory sociální exkluze. Praha: Výzkumný ústav práce a sociálních věcí Praha.

Mareš, P., \& Sirovátka, T. (2008). Sociální vyloučení (exkluze) a sociální začleňování (inkluze). Sociologický časopis, 44(2), 113-138. 
96 Mareš, P. (2000). Chudoba, marginalizace, sociální vyloučení. Sociologický časopis, 36(2), 285-297.

Meeusen, C., De Vroome, T., \& Hooghe, M. (2013). How does education have an impact on ethnocentrism? A structural equation analysis of cognitive, occupational status and network mechanism. International Journal of Intercultural Relations, 37(5), 507-522.

Nekorjak, M., Souralová, A., \& Vomastková, K. (2011). Uvíznutí v marginalitě: vzdělávací trh, „romské školy“ a reprodukce sociálně prostorových nerovností. Sociologický časopis, 47(4), 657-680.

Němec, J. (2009). Sociální a kulturní determinanty a strategie edukace romských žáků. Orbis Scholae, 3(1), 99-120.

Raichová, I. (Ed). (2001). Romové a nacionalismus? Brno: Muzeum romské kultury.

Riessman, C. K. (2008). Narrative Methods for the Human Sciences. Los Angeles: Sage.

Rival, L. (2000). Formal Schooling and the Production of Modern Citizen in the Ecuadorian Amazon. In B. A. U. Levinson (Ed.), Schooling the Symbolic Animal: Social and Cultural Dimensions of Education (s. 108-122). New York: Rowman and Littlefield Publishers, INC. New York: Rowman and Littlefield Publishers, INC. Said, E. W. (2008). Orientalismus: Západní koncepce Orientu. Praha: Paseka.

Schleicher, K., \& Kozma, T. (Ed.). (1992). Ethnocentrism in Education. Frankfurt/M., Berlin, Bern, New York, Paris, Wien: Peter Lang International Academic Publishers.

Steinführerová, A. (2003). Sociálně prostorové struktury mezi setrvalostí a změnou. Historický a současný pohled na Brno. Sociologický časopis, 39(2), 169-192.

Straková, J, Spilková, V., \& Simonová, J. (2013). Názory učitelů základních škol na potřebu změn ve školním vzdělávání. Orbis Scholae, 7(1), 79-100.

Turner, B. S. (1994). Orientalism, Postmodernism and Globalism. London: Routledge.

Williamson, B. (1979). Education, Social Structure and Development. London: The Macmilland Press Ltd.

Irena Kašparová, M.A., Ph.D., Ústav populačních studií Masarykova univerzita, Fakulta sociálních studií irenakasparova@seznam.cz

Mgr. et Mgr. Adéla Souralová, Ph.D., Ústav populačních studií Masarykova univerzita, Fakulta sociálních studií asouralo@fss.muni.cz 